\title{
Heavy Metals and Macronutrients Concentrations in Sewage Sludge Obtained from Decentralized Treatment Facility, Machakos Town, Kenya
}

\author{
Julius Kioko Nzeve*, Sydney Likhumba Ikubano \\ Department of Environmental Sciences, Machakos University, Machakos, Kenya
}

Email address:

jnzeve@gmail.com (J. K. Nzeve)

${ }^{*}$ Corresponding author

\section{To cite this article:}

Julius Kioko Nzeve, Sydney Likhumba Ikubano. Heavy Metals and Macronutrients Concentrations in Sewage Sludge Obtained from Decentralized Treatment Facility, Machakos Town, Kenya. Journal of Health and Environmental Research. Vol. 7, No. 2, 2021, pp. $99-104$. doi: $10.11648 /$ j.jher.20210702.13

Received: April 6, 2021; Accepted: April 19, 2021; Published: April 26, 2021

\begin{abstract}
With the increase of global population, wastewater treatment facilities face a major challenge of managing the large quantities of sewage sludge produced in urban areas. Due to this challenge many wastewater treatment plants have opted for use of sewage sludge as organic fertilizer to boost agricultural production. In Machakos Decentralized Treatment Facility (DFT), sewage sludge is usually sold to locals as fertilizer to boost crop production within the municipality. However, sewage sludge produced in municipal wastewater treatment plants is known to contain various heavy metals that may limit its usage as agricultural fertilizer. Studies have shown that sewage sludge has been associated with heavy metals which are linked to harmful effects on humans and environmental health. This study investigated the levels of various heavy metals and macronutrients from sewage sludge obtained from Machakos town wastewater treatment plant to test its suitability for use as fertilizer. Sewage sludge samples were obtained from the treatment plant at Mitheu and transported to Nairobi Agricultural Research Laboratory (NARL) for analysis of heavy metals ( $\mathrm{Cu}, \mathrm{Zn}, \mathrm{Mn}$, and $\mathrm{Fe}$ ) and macronutrients (N, P, Ca, Mg and K). The results for the heavy metals were $\mathrm{Zn}=171.13 \pm 237 \mathrm{mg} / \mathrm{kg} ; \quad \mathrm{Fe}=17,877 \pm 15,700 \mathrm{mg} / \mathrm{kg} ; \mathrm{Mn}=445.67 \pm 213 \mathrm{mg} / \mathrm{kg}$ and $\mathrm{Cu}=41.1 \pm 16.71 \mathrm{mg} / \mathrm{kg}$ ) while the macronutrients were $\mathrm{K}=0.17 \pm 0.09 \%, \mathrm{P}=1.26 \pm 1.75 \%, \mathrm{~N}=0.74 \pm 0.47 \%, \mathrm{Ca}=0.48 \pm 0.72 \%$ and $\mathrm{Mg}=0.10 \pm 0.06 \%$. The heavy metal concentrations were below Kenya Bureau of Standards (KEBS) and international permissible limits for sewage sludge application in agriculture and therefore deemed safe. The study concluded that the sewage sludge from Machakos Decentralized Treatment Facility is rich in nutrients and thus a potential fertilizing agent that can be used to boost plant growth in agricultural farms. However, it was noted that not all the wastewater produced in Machakos town gets into the DFT for treatment. Therefore, the study recommended that the county government of Machakos should endeavor to enlarge the small DFT treatment plant to accommodate the large quantities of wastewater generated within the town.
\end{abstract}

Keywords: Heavy Metals, Macronutrients, Sewage Sludge, Organic Fertilizer, Machakos Town

\section{Introduction}

Rapid population growth, urbanization and improved coverage in wastewater treatment have led to increased amount of sewage sludge that is generated worldwide. Sewage sludge results from the sedimentation of the suspended solid during wastewater treatment processes [1]. The millions of tons of sewage sludge generated per year poses a challenge on proper disposal both in first and third world countries [2]. The global production of sewage sludge stands at 45 million megagrams of dry matter per year [3] with Europe, East Asia and Northern America being the main producers [4]. Improper management of sewage sludge is a potential threat to the environment for it can affect microorganisms, plants, animals and humans through the food chain [5]. Therefore, sewage treatment and proper disposal of sludge generated by wastewater treatment facilities is a cornerstone of public and environmental health [6]. Globally, one preferred method to remove sewage sludge in industrialized and populous countries is by using it in 
agricultural production [7]. For example, in Europe the use of sewage sludge in agriculture is encouraged as the most viable method of reusing the waste material since it contains high amounts of macronutrients and organic matter up to 50-60\% [8]. It is estimated more than $50 \%$ of sewage sludge produced in Europe is used in agriculture [9]. Additionally, sewage sludge can also be used in reclamation of degraded areas [10].

Due to increased amount of wastewater and sewage sludge produced in Kenya, alternative ways to dispose the residue has become a priority in many urban areas. Dry sludge is rich in nutrients and organic matter that can enhance farm yields [2]. This makes it a sought-after fertilizer as it is cheaper than other fertilizers and also as a better way of waste disposal [11]. It contains Nitrogen, Phosphorous and Potassium and to a lesser extent Calcium and Magnesium. However, sewage sludge may also contain high concentration of heavy metals and pathogenic organisms [12]. It may contain heavy metals such as cadmium, lead and chromium which are extremely toxic and their accumulation in edible plant parts raises health concern especially in leafy vegetables [13]. The sources of sewage heavy metal contamination include unsafe industrial waste disposal such as paint waste and chemical-intensive discharge and anthropogenic sources [14]. Again, waste from municipal and industrial facilities are associated with most heavy metals such as Zinc from galvanisation and cosmetics [15]. Plumbing materials can also enhance $\mathrm{Cu}$ and $\mathrm{Zn}$ content in municipal sewage sludge. Heavy metals ingested in the human body through food chain causes various health risk for example zinc causes anaemia [15]. Other health risks associated with heavy metals include reduced infant growth and development, cancer, organ damage, nervous system damage, and in extreme cases, death [16]. Therefore, the use of sewage sludge in agriculture as an organic fertilizer will depend on the concentrations of heavy metals in the sludge [17]. For example, high levels of Cadmium, Mercury, Lead, Arsenic, Chromium, Copper, Zinc, Nickel and Manganese are of major concern in the environment because they are highly toxic.

The sewage system in Machakos town is not adequate to cope with the human population that has increased tremendously since the inception of devolved system of government in 2013. Currently, Machakos town uses a Decentralized Treatment Facility (DFT) to treat wastewater from the town and this does not cover all the municipal wastewater produced in the town. Large quantities of wastewater are disposed to an old sewerage system that has encountered challenges due to vandalization by urban farmers carrying out agricultural activities adjacent to the plant [18]. The sewage sludge from the DFT is usually removed on weekly basis and left to dry in sludge drying beds. After reaching the desired dryness, the sludge is sold to farmers as soil conditioner or organic fertilizer. Whereas the use of sewage sludge in agriculture may be the best method of disposal, there is need for regular monitoring of the levels of heavy metals in sludge [19]. Monitoring of the sewage sludge produced is currently lacking in many sewage treatment plants leading to informal use of sewage sludge in agriculture without proper quality control [20]. Lack of monitoring means insufficient data on the content of sewage sludge produced. The data on the levels of heavy metals in sewage sludge generated within Machakos town is scanty. This raises questions around the application of sewage sludge in agriculture. Currently, there is urban farming taking place adjacent the Machakos DTF. This includes cultivation of crops and vegetables, and farmers use wastewater from broken sewer lines to irrigate their farms [18]. This study determined the level of selected heavy metals $(\mathrm{Zn}, \mathrm{Cu}, \mathrm{Mn}$ and $\mathrm{Fe}$ ) and five macronutrients (N, P, K, Mg and $\mathrm{Ca}$ ) in sewage sludge obtained from Machakos DFT with the aim of knowing its suitability for use as an agricultural fertilizer. The information is important for policy makers, agricultural and environmental science experts, the farmers and also the community members at large.

\section{Materials and Methods}

\subsection{Study Area}

The study was conducted at Machakos Decentralized Treatment Facility located at Mitheu in Machakos town, which falls in a semi-arid land within Machakos Municipality. Machakos town receives a binomial rainfall of $520 \mathrm{~mm}$ per annum. The temperature ranges from $17^{\circ} \mathrm{C}$ to $37^{\circ} \mathrm{C}$ with the hottest month being March and coldest is July. The geographic positioning of Machakos is $1^{\circ} 31^{\prime} 20.4^{\prime \prime} \mathrm{S}$ and $37^{\circ} 15^{\prime} \mathrm{E}$ and the town is approximated to be $669.70 \mathrm{~km}^{2}$. Machakos town lies on an elevation of $1000-2100 \mathrm{~m}$. The sewage treatment facility supports different sectors such as hospitals, businesses, educational institutions and residential premises. Subsistence farming of maize is common in the area coupled with vegetable urban farming including tomatoes, kales, spinach among others.

\subsection{Collection of Samples, Preparation and Laboratory Analysis}

Sewage sludge samples were obtained at the Machakos town wastewater Decentralized Treatment Facility. The sludge samples collected were in form of dewatered cakes which were drawn from heaps of dry sewage sludge. The samples were collected in triplicates on weekly basis in January, 2020. The samples were labelled appropriately for heavy metals and macronutrients. They were transported in plastic containers for laboratory analysis at Nairobi Agricultural Research Laboratory (NARL) at Kabete, Nairobi for heavy metal and macronutrient analysis. The samples were ground for homogeneity and sieved before digestion for heavy metal analysis. $2 \mathrm{~g}$ of ground sewage sludge were weighed and digested using concentrated Nitric acid. Potassium (K) was determined with a flame photometer, phosphorus (P) with determined calorimetrically on spectrophotometer, N-total was measured by distillation followed by titration with standardized $\mathrm{HCl}$; and $\mathrm{Ca}, \mathrm{Mg}, \mathrm{Cu}, \mathrm{Zn}, \mathrm{Mn} \& \mathrm{Fe}$ were determined using Atomic Absorption Spectrophotometer (AAS). 


\subsection{Data Analysis}

Data from the laboratory analysis for the heavy metals and macronutrients was analyzed using descriptive statistics. This was done using IBM SPSS version 21 where means, range and standard deviations were obtained. The mean heavy metal concentrations in the sewage sludge were then compared with United States Environmental Protection Agency (US EPA), European Union (EU) guidelines, Food and Agricultural Organization (FAO) set guidelines and Kenya Bureau of standards (KEBS) guidelines for sewage sludge made for use in agriculture.

\section{Results and Discussions}

\subsection{Level of Heavy Metals in the Sewage Sludge}

The application of sewage sludge as an organic fertilizer can lead to accumulation of heavy metals in agricultural soils. The results of heavy metal concentrations $(\mathrm{Zn}, \mathrm{Cu}, \mathrm{Fe}$ and $\mathrm{Mn}$ ) obtained from sewage sludge in the study are presented in Table 1. The comparison of heavy metal concentrations in sewage sludge and other national and international set standards are presented in Table 2.

Table 1. Heavy metal concentrations ( $\mathrm{Mg} / \mathrm{kg}$ dry matter) in Sewage sludge samples.

\begin{tabular}{llll}
\hline Heavy metal & Minimum & Maximum & Mean \pm SD \\
\hline Zinc & 21.70 & 445.00 & $171.13 \pm 237.50$ \\
Copper & 28.30 & 60.00 & $41.10 \pm 16.71$ \\
Iron & 623.00 & 31301.00 & $17897.00 \pm 15700.88$ \\
Manganese & 250.00 & 672.00 & $445.66 \pm 212.66$ \\
\hline
\end{tabular}

SD - Standard Deviation

\subsubsection{Zinc}

The mean $\mathrm{Zn}$ value in this study was $171.13 \pm 237.50 \mathrm{mg} / \mathrm{kg}$ which was way below the findings obtained from a waste water treatment plant sludge in China [21], but higher than $100 \mathrm{mg} / \mathrm{kg}$ recorded in Sweden [22]. The zinc contents were also higher compared to $51.6 \pm 4.8 \mathrm{mg} / \mathrm{kg}$ reported by Moturi et al., [13]. Zinc is an essential micronutrient that affects metabolic processes of plants if it exceeds the permissible limits. The source of $\mathrm{Zn}$ to the environment can be from batteries, paints, plastics, polymer stabilizers and from printing arts [23]. Compared to US EPA guidelines and Kenya Bureau of standards permissible limits, the sewage sludge zinc composition was below the limits of $2800 \mathrm{mg} / \mathrm{kg}$ and $1850 \mathrm{mg} / \mathrm{kg}$ dry weight respectively, hence considered safe for use in agriculture (Table 2).

\subsubsection{Copper}

The $\mathrm{Cu}$ concentrations ranged from $28.3-60.0 \mathrm{mg} / \mathrm{kg}$ with a mean value of $41.1 \pm 16.71 \mathrm{mg} / \mathrm{kg}$. This range was lower than $895.49-1788.70 \mathrm{mg} / \mathrm{kg}$ recorded in Ruai sewage treatment plant [24], $104-194 \mathrm{mg} / \mathrm{kg}$ from Poland [25], and 103-696 mg/kg obtained in Swaziland [26]. The mean $\mathrm{Cu}$ levels was lower compared to $193 \pm 9.6 \mathrm{mg} / \mathrm{kg}$ reported in sewage sludge obtained from Taiwan wastewater treatment plant [27]. However, it was much higher than $0.208 \mathrm{mg} / \mathrm{kg}$ reported in South Africa [28]. Though a heavy metal, $\mathrm{Cu}$ is an essential component of various proteins like plastocyanin and thus an important micronutrient required by plants. Sources of copper into the environment include several industries which deal with paint, textile, metallurgical, plant protection products and fertilizer [29]. The US EPA guidelines set permissible limits at $1500 \mathrm{mg} / \mathrm{kg}$. The copper concentration in Machakos Decentralized Treatment Facility was below the set national and international guidelines on sewage sludge made for use in agriculture (Table 2)

\subsubsection{Iron}

The mean Fe level in this study was high at $17877 \pm 15700.88 \mathrm{mg} / \mathrm{kg}$. This was higher than $45 \pm 2.335$ $\mathrm{mg} / \mathrm{kg}$ reported from a wastewater treatment plant in Eastern Cape town, South Africa [30], 8.559 - $36.188 \mathrm{mg} / \mathrm{kg}$ recorded from Swaziland [26] and those reported from Sweden $(4400-150,000 \mathrm{mg} / \mathrm{kg})$ [31]. However, the Fe level in this study were comparable with $4737.08-65203.05 \mathrm{mg} / \mathrm{kg}$ obtained at Ruai wastewater treatment plant [24]. Fe is an essential element and an important nutrient for some plants. Iron is also a constituent of major vitamins required by the human body.

\subsubsection{Manganese}

The mean Mn recorded in this study (445.67 $\pm 212.66 \mathrm{mg} / \mathrm{kg}$ ) was lower than $750 \mathrm{mg} / \mathrm{kg}$ obtained in sludge from Janow Lubelski waste water treatment plant in South eastern Poland [32]. However, the levels were higher than $228 \pm 23 \mathrm{mg} / \mathrm{kg}$ recorded also in Poland [33]. Excessive accumulation of manganese in plants reduces the photosynthesis rate. The concentration of manganese was second highest micronutrient recorded from this study. No limits of manganese were found recorded on sewage sludge regulatory set limits for national and international standards (Table 2).

Table 2. Comparison of the sewage sludge contents with the permissible set limits.

\begin{tabular}{llllll}
\hline Element & $\begin{array}{l}\text { Mean (mg/kg) } \\
\text { content of sewage } \\
\text { sludge }\end{array}$ & $\begin{array}{l}\text { EU Guidelines } \\
(\mathbf{m g} / \mathbf{k g ~ D W ) ~ [ 3 4 ] .}\end{array}$ & $\begin{array}{l}\text { Kenya Bureau of } \\
\text { Standards Guidelines } \\
(\mathbf{m g} / \mathbf{k g ~ D W ) ~ [ 3 5 ] . ~}\end{array}$ & $\begin{array}{l}\text { US EPA } \\
\text { Guidelines } \\
\text { (Mg/kg DW) [36]. }\end{array}$ & $\begin{array}{l}\text { FAO set } \\
\text { guidelines } \\
(\mathbf{m g} / \mathbf{k g}) \text { [37]. }\end{array}$ \\
\hline Zinc & 171.13 & $2500-4000$ & 1850 & 2800 & $\begin{array}{l}\text { South Africa } \\
\text { Guidelines [38]. }\end{array}$ \\
Copper & 41.10 & $1000-1750$ & 300 & 1500 & 200 \\
Iron & 17897 & - & - & - & - \\
Manganese & 445.66 & - & - & - & - \\
\hline
\end{tabular}




\subsection{Macronutrients Concentration in Sewage Sludge}

Nutrients are essential for plant and microbial growth in agricultural soils. In this study five macronutrients were examined and the results are presented in Table 3. They included Nitrogen, Phosphorus, Potassium, Calcium and Magnesium. The results were, Nitrogen $0.74 \pm 0.47 \%$, Phosphorus 1.26 \pm 1.75 , Potassium $0.17 \pm 0.09 \%$, Magnesium $0.10 \pm 0.06 \%$, and Calcium $0.48 \pm 0.72 \%$. The concentration of Phosphorus was higher than the other macronutrients followed by nitrogen (Table 3). Sewage sludge is used in agriculture as a reliable source of nitrogen and phosphorous [10]. Nitrogen and phosphorous are essential nutrients for plant growth. The total N, P and $\mathrm{K}$ content had a range of $0.47-1.28 \%, 0.21-3.28 \%$ and $0.10-0.27 \%$ respectively (Table 3). The N, P and K mean concentrations obtained in this study were lower than $3.02 \%, 2.06 \%$ and $1.59 \%$ respectively obtained frow sewage sludge in Kolkata, India [39]. The mean concentrations $\mathrm{N}$ was within acceptable specific requirements of less than $1 \% \mathrm{~N}$ for organic manures in Kenya [35].

Table 3. Macro element concentrations (\%) in Sewage sludge dry matter samples.

\begin{tabular}{llll}
\hline Macronutrient & Minimum & Maximum & Mean \pm SD \\
\hline Nitrogen & 0.47 & 1.28 & $0.74 \pm 0.47$ \\
Phosphorus & 0.21 & 3.28 & $1.26 \pm 1.75$ \\
Potassium & 0.10 & 0.27 & $0.17 \pm 0.09$ \\
Magnesium & 0.04 & 0.15 & $0.10 \pm 0.06$ \\
Calcium & 0.06 & 1.31 & $0.48 \pm 0.72$ \\
\hline
\end{tabular}

\section{Conclusion and Recommendations}

The levels of heavy metals analyzed in this study were below national and international set standards for sewage sludge application in agriculture and therefore deemed safe in the short term. However, the study recommends further research to ascertain the levels of persistence toxic elements such as Cadmium, Lead, Chromium, Mercury and other environmental contaminants including pharmaceuticals and pathogenic microorganisms that were not studied due to financial constraints. As per the macronutrient levels observed in this study, its concluded that the sewage sludge from Machakos Decentralized Treatment Facility is rich in nutrients and thus a potential fertilizing agent that can be used to boost plant growth. During the study, it was also observed that not all the wastewater from the municipality undergoes treatment through the Decentralized Treatment Facility from where sludge samples were obtained. This is because, Machakos town lacks a fully developed sewer line system, and therefore its recommended that the county government should ensure an elaborate sewage treatment system that covers the entire municipality.

\section{Acknowledgements}

The authors acknowledge and appreciate National
Agricultural Research Laboratory (NARL), Nairobi, for the use of their laboratory during laboratory sample analysis.

\section{Conflict of Interest}

The authors declare that they have no competing interests.

\section{References}

[1] Lamastra, L., Suciu, N. A. and Trevisan, M (2018). Sewage sludge for sustainable agriculture: Contaminants' contents and potential use as fertilizer. Chem. Biol. Technol. Agric. 2018, 5, 1-6.

[2] Alvinash. D., Anupam. M and Kam. N. T (2019): Comparative study of Different Sewage farming on soil Quality: A Review. International Journal of Trend in Scientific Research and Development (IJTSRD), ISSN: 24566470, Volume 3, Uttar Pradesh, India.

[3] Zhang, Q., Hu, J., Lee, D.-J., Chang, Y and Lee, Y.-J. (2017). Sludge treatment: current research trends. Bioresour. Technol. 243, 1159-1172. https://doi.org/10.1016/j.biortech.2017.07.070.

[4] Shaddel, S., Bakhtiary-Davijany, H., Kabbe, C., Dadgar, F and Østerhus, S. W. (2019). Sustainable sewage sludge management: from current practices to emerging nutrient recovery technologies. Sustainability 11. https://doi.org/10.3390/su11123435.

[5] Correia, A. A. S., Matos, M. P. S. R., Gomes, A. R and Rasteiro, M. G (2020). Immobilization of Heavy Metals in Contaminated Soils-Performance Assessment in Conditions Similar to a Real Scenario. Appl. Sci. 2020, 10, 7950.

[6] Kominko, H., Katarzyna, G., Zbigniew, W., and Katarzyna, W (2018). Sustainable Management of Sewage Sludge for the Production of Organo-Mineral Fertilizers. Waste Biomass Valor (2018) 9: 1817-1826 DOI 10.1007/s12649-017-9942-9.

[7] Ig. F., Erman. M and Sonmez, F (2019): Determining the effects of Sewage sludge and Rhizobium inoculation on nutrients and heavy metal content of Lentil (Lens culinaris medics.) Applied Ecology and Environmental Research 17 (2): 2701-2719, Turkey.

[8] Burducea, M., Lobiuc, A., Asandulesa, M., Zaltariov, M.-F., Burducea, I., Popescu, S. M. and Zheljazkov, V. D (2019). Effects of Sewage Sludge Amendments on the Growth and Physiology of Sweet Basil. Agronomy 2019, 9, 548. https://oi.org/10.3390/agronomy909054.

[9] Kelessidis, A and Stasinakis, A. S (2012). Comparative study of the methods used for treatment and final disposal of sewage sludge in European countries. Waste Management. 32, 11861195. https://doi.org/10.1016/j.wasman.2012.01.012.

[10] Lasaridi, K.-E., Manios, T., Stamatiadis, S., Chroni, C and Kyriacou, A (2018). The Evaluation of Hazards to Man and the Environment during the Composting of Sewage Sludge. Sustainability 2018, 10, 2618.

[11] Usman K., Sarfaraz K., Said G., Muhammad, U. K., Niamatullah. K., Muhammad, A. K and Shad, K. K. (2012). Sewage Sludge: An Important Biological Resource for Sustainable Agriculture and Its Environmental Implications. American Journal of Plant Sciences, 2012, 3, 1708-1721 http://dx.doi.org/10.4236/ajps.2012.312209. 
[12] Latosinska, J (2020). Risk assessment of soil contamination with heavy metals from sewage sludge and ash after its incineration. Desalin. Water Treat. 2020, 199, 297-306.

[13] Moturi. K. M., Jama. K., Makhone. S. N and Kimaru. L (2018): Assessment of heavy metals in sewage sludge and their accumulation in cabbage (Barassica Oleracar var capitals). Shaw. R. S. (ed).

[14] Victor. O. S., George. O. A., Emily. N., George. M. O., Gloria A. M and James. J. O (2017): Determination and removal of efficiency of heavy metals by a conventional activated sludge at a municipal wastewater treatment plant in Kisumu city, Kenya. Research Journal of Chemical Sciences Vol. 7 (8), 1925, August (2017).

[15] Wamalwa. K. M., Lusweti. J., Lutta. S., Anditi. B. C., Imbila. O. M and Muthoka. T. M (2015): Variation of pollutant levels in vegetables: A case study of Kitale Municipality, TransNzoia County, Kenya. African Journal of Education, Science, and Technology, January 2015 Vol 2, No. 2.

[16] Mahurpawar, M. (2015). Effects of Heavy Metals on Human Health. Social Issues and Environmental Problems. Retrieved from http://granthaalayah.com/Articles/Vol3Iss9SE/152_IJRG15_S 09_152.pdf.

[17] Latosinska, J., Kowalik, R and Gawdzik, J (2021). Risk Assessment of Soil Contamination with Heavy Metals from Municipal Sewage Sludge. Appl. Sci. 2021, 11, 548. http://doi.org/10.3390/app11020548.

[18] Kitulu, L., Nzeve, J. K., Waswa, F., Kitur, E and Shitanda, D. (2020). Irrigation water quality analysis of Mitheu Stream in Machakos Municipality, Kenya. African Journal of Environmental Science and Technology, 14 (9), 241-249. https://doi.org/10.5897/AJEST2020.2849.

[19] Lynn, R. M. (2019): Heavy metal phytoextraction in sewage sludge using sunflower.

[20] Sushanta, S., Bholanath, S., Sajal, P., Biplab, P. and Gora, C. H. (2017). Agricultural Use of Sewage Sludge in India: Benefits and Potential Risk of Heavy Metals Contamination and Possible Remediation Options - A Review. International Journal of Environmental Technology and Management. doi: 10.1504/IJETM.2017.10010695.

[21] Yang, T., Huang, H. J and Lai, F. Y (2017). Pollution Hazards of Heavy Metals in Sewage Sludge from Four Wastewater Treatment Plants in Nanchang, China. Trans. Nonferrous Met. Soc. China 2017, 27, 2249-2259. DOI: 10.1016/S10036326(17)60251-6.

[22] Mattsson, A., Finnson, A and I'Ons, D (2017). Heavy Metal Content of Swedish Municipal Wastewater sludge - status and goals. Water Science Technology 2017, 76, 869-876. DOI: 10.2166/wst.2017.277.

[23] Wuana, R. A. and Okieimen, F. E (2011). Heavy Metals in Contaminated Soils: A Review of Sources, Chemistry, Risks and Best Available Strategies for Remediation. Int. Sch. Res. Not. 2011.

[24] Mbugua, P. K. (2015); Suitability of waste water sludge for Agricultural use: A case study of Ruai Sewage Treatment Plant Nairobi, Kenya. Msc Thesis, Kenyatta University, Nairobi, Kenya.

[25] Tytła, M (2019). Assessment of Heavy Metal Pollution and
Potential Ecological Risk in Sewage Sludge from Municipal Wastewater Treatment Plant Located in the Most Industrialized Region in Poland-Case Study. Int. J. Environ. Res. Public Health. 2019, 16, 2430.

[26] Tiruneh, A. T., Fadiran, A. O and Mtshali, J. S (2014). Evaluation of the risk of heavy metals in sewage sludge intended for agricultural application in Swaziland. Intl. J. Env. Sci. 2014, 5, 197-216.

[27] Wang Ming-Huang, Chih-Feng Chen, Yun-Ru Ju, Mei-Ling Tsai, Chiu-Wen Chen and Cheng-Di Dong (2021): Distribution and environmental risk assessment of trace metals in sludge from multiple sources in Taiwan, Journal of Environmental Science and Health, Part A, DOI: 10.1080/10934529.2021.1887687.

[28] Nyamukamba, P., Moloto, M. J., Tavengwa, N and Ejidike, I. P (2019). Evaluating Physicochemical Parameters, Heavy Metals, and Antibiotics in the Influents and Final Effluents of South African Wastewater Treatment Plants. Pol. J. Environ. Stud. 2019, 28, 1305-1312. DOI: 10.15244/pjoes/85122.

[29] Smiljani'c, S., Tesan-Tomi'c, N and Perusic, M (2019). The Main Sources of Heavy Metals in the Soil and Pathways Intake. In Proceedings of the Conference: Europen Energy Market, Ljubliana, Slovenia, 18-20 September 2019.

[30] Agoro, M A., Abiodun O. Adeniji., Martins A. Adefisoye and Omobola O. Okoh (2020). Heavy Metals in Wastewater and Sewage Sludge from Selected Municipal Treatment Plants in Eastern Cape Province, South Africa. Water 2020, 12, 2746; doi: $10.3390 / w 12102746$.

[31] Eriksson, J (2001). Concentrations of 61 Trace Elements in Sewage Sludge, Farmyard Manure, Mineral Fertiliser, Precipitation and in Oil and Crops; Swedish Environmental Protection Agency: Stockholm, Sweden, 2001; Volume 5159.

[32] Antonkiewicz J., Kołodziej B., Bielińska E. J and GleńKarolczyk K. (2019). Research on the uptake and use of trace elements from municipal sewage sludge by multiflora rose and Virginia fanpetals. Journal of Elementology 24 (3): 9871005. DOI: 10.5601/jelem.2018.23.4.1757.

[33] Bożym, M and Siemiątkowski, G (2018). Characterization of composted sewage sludge during the maturation process: a pilot scale study. Environmental Science and Pollution Research (2018) 25: $34332-34342$ https://doi.org/10.1007/s11356-018-3335-x.

[34] European Commission (1986). Council Directive of 12 June 1986 on the Protection of the Environment, and in Particular of the Soil, When Sewage Sludge Is Used in Agriculture (86/278/EEC); European Commission: Brussels, Belgium, 1986.

[35] KEBS (2011). KS2290: 2011, 2011. Organic fertilizer specification, Kenya Standards Bureau.

[36] USEPA (United States Environmental Protection Agency) (1995). A Guide to the Biosolids Risk Assessments for the EPA Part 503 Rule; U.S. Environmental Protection Agency Office of Wastewater Management: Washington, DC, USA, 1995.

[37] FAO (1992). Agricultural Use of Sewage. In Waste Water Treatment and Use in Agriculture, FAO Irrigation and Drawing Paper 47; Food and Agriculture Organization of the United Nations: Rome, Italy, 1992. 
[38] Water Research Commission (2009). Guidelines for the Utilisation and Disposal of Wastewater Sludge. Vol. 2. Requirements for the Agricultural Use of Wastewater Sludge; WRC Report no: TT 262/06; WRC: Pretoria, South Africa, 2009.
[39] Saha, S., Saha, B. N., Hazra, G. C., Pati, S., Pal, B., Kundu, D. Ghosh, A., Chatterjee, N and Batabyal, K. (2018). Assessing the Suitability of Sewage-Sludge Produced in Kolkata, India for Their Agricultural Use. Proc Indian Natn Sci Acad 84 No. 3 September 2018 pp. 781-792. 